A revised version of this paper was published as:

Hirata, K. (2002). Whither the developmental state? The growing role of NGOs in Japanese Aid Policy Making. Journal of Comparative Policy Analysis, vol 4, no. 3.

\title{
Whither the Developmental State? The Growing Role of NGOs in Japanese Aid Policy Making
}

By Keiko Hirata, University of California, Irvine

Key words: Japan, developmental state, civil society, nongovernmental organizations (NGOs), official development assistance (ODA)

\begin{abstract}
Japan is often characterized as a developmental state, i.e., a state with a strong and autonomous bureaucratic leadership that directs the economy toward achieving developmental goals. This study challenges the developmental state model, arguing that the once-powerful Japanese bureaucracy has lost much of its authority and is no longer autonomous from societal forces. By focusing on the growing role of nongovernmental organizations (NGOs) in Japan's official development assistance (ODA) policy making, this study shows how the non-governmental sector has begun to challenge bureaucratic dominance and reshape state-civil society relations in Japan.
\end{abstract}


In recent years Japan's prolonged economic recession has renewed debates on the role of the Japanese bureaucracy in directing national economic policy. Some argue that despite the economic downturns of the 1990s the bureaucracy has retained its authority and power and will eventually rescue Japan from recession. From this perspective, Japan has continued to be a "developmental state" where elite, economic bureaucrats take on developmental functions by "guiding" the national economy to promote economic growth (Johnson, 1995; Fingleton, 1995). Others contend that recent economic and political crises in Japan have seriously damaged the bureaucracy's reputation and weakened its authority. In their view, the Japanese bureaucracy is no longer autonomous from society; it has been forced to compromise with domestic demands to undertake extensive political and economic reforms (Curtis, 1999a; Friedman, 1999).

This study examines one particular policy area critical to Japanese reform efforts: overseas development assistance (ODA). The study supports the view that bureaucratic authority has been substantially weakened during the last decade, particularly in the area of ODA. The study argues that the developmental state model, based on Japan's rapid economic development from the 1950s to the 1970s, is increasingly unsuitable for explaining Japan's political economy, especially with regard to aid policy. The developmental state model exaggerates the power of the bureaucracy in economic policy making. It overstresses bureaucratic autonomy and neglects the increasingly important role of civil society, particularly non-governmental organizations (NGOs), in aid policy making. As Tokyo has faced a crisis of authority, the Japanese citizenry is demanding fuller accountability from the bureaucracy in all political and economic areas, including foreign aid.

This article will first refute the applicability of the developmental state model to Japanese aid policy making and offer a pluralistic explanation for the growing role of Japanese NGOs. It will then examine factors that have contributed to changing relations 
between the bureaucracy and NGOs. Specifically, it will analyze two factors accounting for authority crisis (i.e., economic recession and a series of corruption scandals in Japan) and a factor that has contributed to the rise of NGOs (i.e., the erosion of social values in the post-developmental state). Finally, the study will examine how NGOs participate in ODA policy making and interact with the bureaucracy. It will discuss the historical development of Japanese NGOs, their relationship with the Ministry of Foreign Affairs (MOFA) - one of the most prominent bureaucratic agencies in charge of ODA - and the diversity within the NGO community in interacting with MOFA.

\section{Contending Approaches to Aid Policy Making}

\section{Developmental State Model}

The developmental state model emphasizes the role of the bureaucracy in promoting economic growth. In his seminal work MITI and the Japanese Miracle, Johnson (1982) presents a developmental state model in which Japanese bureaucracy is autonomous and insulated from political and societal forces. Johnson maintains that the Japanese bureaucracy, and the Ministry of International Trade and Industry (MITI) in particular, exerted a strong leadership role in the 1960s and 1970s in guiding and protecting Japanese strategic industries by means of "administrative guidance," a practice by which the ministry solicited compliance for its policies from target industries. In Johnson's view, MITI brought about industrial structural change in Japan in the 1960s (i.e., a shift from light industry to chemical and heavy industries), which in turn contributed to Japan's rapid economic growth.

According to Johnson, several attributes characterize the bureaucratic leadership. Japanese bureaucrats are highly skilled and well-motivated individuals who are "the most talented graduates of the best universities" in Japan (p. 20). In addition, civil servants are recruited through a vigorous national examination system and, once employed, go through extensive training in their respective ministries. The skills and knowledge they 
acquire allow them to carry out their administrative duties with no major interruptions from politicians. Also, the bureaucracy is able to establish close relationships with the corporate sector through a practice called amakudari (“descent from heaven") through which former officials take positions in top posts in private corporations after retirement (Johnson, 1982).

One of the most elaborate proponents of Johnson's developmental state approach is Arase (1994, 1995), who focuses, in his study on Japanese aid, on institutional coordination between the business sector and the bureaucracy - with MITI ultimately in charge. Unlike pluralists, Arase (1995) emphasizes cooperation and collaboration rather than conflict among those involved in decision making. Arase stresses that the bureaucratic actors are able to iron out their conflicting views and work together with the business sector to achieve a national agenda - that is, a single-minded pursuit of mercantile interests. Arase places special emphasis on the allegedly cordial relationship between business and the bureaucracy (mainly MITI). Yet in his view, as in Johnson's, the relationship between the bureaucracy and business is not equal:

The private sector is subordinate to and dependent on bureaucratic affiliations, licenses, and approvals to have membership in this system, and it must follow administrative guidance as an organizational norm (Arase, 1995, p. 246).

Arase (1995) rejects a pluralist view of Japanese aid policy making as it overlooks "the autonomy that states enjoy" (p. 234). He goes so as far as to say that "in neither prewar nor postwar Japan did Japanese civil society design and authorize the Japanese state" (p. 244):

The bureaucracy is too strong and partisan, the role of the legislature is too weak, and the linkages between bureaucratic actors and the private sector are too institutionalized and exclusionary to fit the basic premises of pluralist models of policy making. ODA policy is anything but the 
product of freely competing, diverse societal interests working through a neutral and politically accountable state (p. 243).

The developmental state model correctly stresses that bureaucrats, not politicians, are the principal actors in aid policy making. But this approach overemphasizes unity between the state and society, presenting an image of a monolithic "Japan, Inc." This view is misleading as it ignores the multiplicity of interests and actors in Japanese aid, including citizens' groups. The lack of attention to citizens' groups is perhaps explained in part by the fact that few Japanese citizens' groups were involved in issues of ODA until the late-1980s. Yet at the beginning of this new century the situation is different: NGOs are now indispensable actors in aid policy making. The developmental state model overstresses continuity, since it views mercantilism as the overriding and continuous factor in shaping Japanese aid policy.

As civil society increases its influence in aid policy, a new approach to understanding aid decision making is necessary, one that takes into account more fully the roles of citizens' groups. This new approach will fall within the pluralist school of thought.

\section{Pluralistic Approach}

Pluralists contend that a multitude of competing actors inside and outside the bureaucracy participate in decision making. From a pluralist perspective, it is necessary to consider how various governmental and societal groups work to defend and promote their competing interests.

Scholars have identified a number of different actors outside the bureaucracy that help to shape government policy making in general, if not specifically, in regard to ODA. First, some point out the increasing autonomy of the Japanese corporate sector, arguing that as the Japanese economy has grown, Japanese businesses have become more independent of the state (Pempel, 1998; Uriu, 1996). ${ }^{1}$ Second, as noted by Krauss 
(1989), politicians are playing an increasingly independent role. Under the 1955 system, characterized by one-party dominance by the Liberal Democratic Party (LDP) from 1955 to 1993, politicians gained knowledge and expertise in specific issue areas previously monopolized by bureaucrats. Third, business and agricultural interest groups in Japan are actively exercising their influence over trade issues (Richardson and Flanagan, 1984). Fourth, citizens' groups have had a significant impact on government policy making in certain areas, especially in regard to the environment. Beginning in the 1960s, citizens' groups emerged to politicize environmental problems in Japan (e.g., Minamata disease caused by methyl mercury poisoning) and pressure local and central government officials for action. These citizens' groups succeeded in bringing about change in Japan's environmental policy largely because they succeeded in persuading local governments to pressure the central government (McKean, 1976; Pempel, 1982).

Much of this work using a pluralist framework has focused on policy making generally and has not yet been applied to ODA policy making. This study will adopt the pluralist framework as an analytical tool for interpreting ODA decision making. Three main points are made. First, the state is not insulated from societal forces but is directly influenced by them. Societal groups have many points of access to the policy-making process, and there is a significant degree of responsiveness by the state to social interests. The state is not autonomous but is constrained by the countervailing powers of civil society and businesses. As Muramatsu and Krauss (1987) claim, the state is "penetrated" by societal groups (p. 536).

Second, pluralism within ODA operates as a form of controlled pluralism rather than a free-for-all polyarchy (Dahl, 1961) and all societal pressure groups are not considered to have equal resources, access, or influence. While pluralism is common in governmental policy making in many parts of the world, pluralism in Japan has its own special characteristics. Rather than being a form of polyarchy with a wide representation of participants in decision making or policy determined by open-ended lobbying of 
competing pressure groups on a relatively weak government, Japan's pluralism is patterned and highly institutionalized.

In a traditional pluralistic system, as in the US, decision-making lies in the hands of the legislative and executive branches. In a patterned pluralistic system, different groups vie for power, but the bureaucracy frequently makes the final decision in policy matters while attempting to accommodate various interestsduring the decision-making process. In their analysis of economic and political policy making (e.g., banking and environmental laws), Muramatsu and Krauss (1987) note that the Japanese bureaucracy has highly institutionalized relationships with interest groups. In the case of ODA, policy making is patterned and controlled, with the bureaucracy — primarily led by MOFA interacting with societal (i.e., NGOs and corporations) and political actors (i.e., the legislature).

Unlike the model of Muramatsu and Krauss (1987), however, this study contends that the role of politicians, though increasing, is still limited. While members of the executive branch (i.e., prime minister and his advisors) take part in high-level aid decision making, they do not participate in day-to-day ODA policy making. Most aid decision making involves low-level, routine operating procedures. Although some lowerranking politicians are now demanding an increasing role in aid policy making and a shift of authority from the bureaucracy (see International Development Journal, 1998; International Development Journal, 1999a; International Development Journal, 1999b), politicians are not yet consistently involved with foreign aid decisions.

Third, in the patterned pluralist system, state-society relations are not always antagonistic. They can also be characterized by cooperation and collaboration. Through institutionalized relationships, the state and societal groups can work together to achieve common goals. Such cooperation is found in the aid policy making process where the bureaucracy has begun to recognize the increasing influence of NGOs in society and has started accommodating their demands for ODA reform. For example, as discussed 
below, MOFA accepted an NGO request to establish regular meetings between the ministry and NGOs to discuss a wide range of issues related to not only state assistance to Japanese NGOs but also the involvement of NGOs in Japan's foreign aid policy making and implementation.

In summary, the state, represented by the bureaucracy, has lost the political leadership that it once enjoyed. In turn, societal groups have been demanding greater control over the policy process and the weakening of the formal powers of the bureaucracy. The bureaucracy has been increasingly on the defensive, and it has no choice but to accept demands from civil society. At the same time, the state has begun to integrate societal groups into the policy-making process. Thus state-society relations contain elements not only of conflict but also of cooperation.

\section{Factors Contributing to Changes in ODA}

The weakening of state authority and the rise of citizens' movements have resulted largely from three new phenomena in post-Cold War Japan: (1) the long recession since the early-1990s that symbolizes the end of the developmental state model; (2) the instability of political leadership; and (3) the psychological confusion pervasive among Japan's youth (Castells, 1998). These phenomena have These phenomena, taken together, have shaken up Japan, and, in particular, have had a major impact on Tokyo's aid policy.

\section{Economic Recession}

According to Katz (1998), the Japanese developmental state is a "system that soured" (p. 21). In the past, developmental state policies (e.g., a variety of so-called administrative guidance and massive subsidies to strategic industries) brought prosperity to the Japanese people in just a few decades. Japan's rapid economic growth from the 1950s to the early-1970s was, as claimed by the proponents of the developmental state approach, a "miracle" (Johnson, 1982, p. 3). This miracle, however, did not last. By the 
1970s, the Japanese economy had fully matured, and Japan's developmental state strategies became counterproductive to future economic development. The protectionof inefficient industries from foreign competition began to debilitate Japan, resulting in a dual economy: one of strong exporting industries (e.g., autos) and the other of weak, backward domestic sectors (e.g., chemicals). The dual system began to clog the arteries of Japan in the global economy: while efficient exporters went offshore to cut costs and hollowed out Japan, inefficient sectors remained in the country. As a result, Tokyo's productivity dragged and the Japanese economy stagnated (Katz, 1998; Pempel, 1998). The economic recession that started in the 1990s demonstrates that Japan's developmental state policies no longer function well. The recession manifests the obsolete, increasingly irrelevant role of the state in guiding and protecting inefficient sectors in Japan.

\section{Bureaucratic Corruption}

Public confidence in the government was further undermined in the 1990s due to widespread corruption and scandals involving bureaucratic leaders, including highranking civil servants. In 1988 the first scandal that deeply affected the Japanese political and economic environment broke, revealing that the Recruit Corporation, an informationindustry company, had bribed dozens of bureaucrats and politicians in the ruling Liberal Democratic Party (LDP), opposition parties, and high-ranking bureaucrats. This scandal contributed to the downfall of Prime Minister Noboru Takeshita in 1989, whose popularity plummeted following the revelation of the bribes. After the Recruit incident, a series of corruption scandals infuriated the public, including the 1992 Sagawa Kyubin (trucking firm) scandal, the 1995 jusen (housing loan firms) bailout, and the $1996 \mathrm{HIV}$ tainted blood scandal. ${ }^{2}$ These cases exposed unethical and illegal behavior of business leaders, politicians, and elite bureaucrats, deepening public discontent with the political 
and economic system in Japan. Eventually, in 1993, the culmination of public frustration with the LDP-ruled government ended the "1955 system," in which the LDP had governed Japan without interruption since 1955.

Of course, qrongdoings by Japan’s political and economic leaders had undoubtedly also occurred prior to the 1990s. "Money politics" had begun in Japan in the 1970s under the rule of Prime Minister Kakuei Tanaka, who was arrested after his term of prime ministership (1972-1974) with a charge of receiving bribes from the Lockheed Aircraft Corporation in the United States. The Japanese public had previously been aware of illegal money-raising activities of politicians who kept close ties with big business.

What distinguishes the recent scandals from earlier ones, however, is the pervasiveness of structural corruption, involving not only politicians and big businesses but also bureaucrats in powerful ministries, such as the Ministry of Finance and MITI (Nikkei Weekly, 1998). In the past, the Japanese people tolerated corrupt behavior by politicians and business leaders as an unavoidable side effect of Japan's rapid economic growth. Also, the public distinguished bureaucrats from politicians and big businesses in that the former was considered untainted with corruption. Civil servants' long-held reputation for selfless devotion to Japan's economic development brought them power and prestige. However, the status of elite bureaucrats substantially declined in the 1990s, due to the pervasiveness of money politics. The Recruit scandal resulted in the arrests for corruption of two high-ranking officials: former vice minister of the Ministry of Labor Takashi Kato and former vice minister of Education Kunio Takashi. Subsequent allegations of corruption have continued to taint the once highly respected bureaucracy. 
The public has begun to take bureaucratic corruption seriously, as indicated by frequent citizens' letters to newspapers, media reports on public discontent, and seminars and conferences on corruption issues.

In the 1990s, corruption scandals gained high visibility, and involved many other ministries with close ties with the private sector. MOF, the most powerful and prestigious ministry in Japan, became seriously mired in several scandals, one of which eventually forced Minister of Finance Hiroshi Mitsuzuka to resign. In 1998, the media reported that MOF took action (e.g., forced resignations, reductions of salary, written or oral warnings) against 112 of its own officials for inappropriate behavior in dealing with financial institutions in Japan. Among those reprimanded was a MOF official heading the General Affairs Bureau within the Overseas Economic Cooperation Fund (OECF), the former Japanese ODA loan agency (Asahi Shimbun, 1998).

In 2000-2001, scandals involving officials in MOFA, a ministry that had not previously been seriously tainted by corruption scandals,erupted. Several MOFA officials were arrested or reprimanded on charges of fraud, embezzlement, or billpadding. These incidents have seriously hurt the reputation of the ministry, once revered as a prestigious organization of elite diplomats. In one case, a MOFA official was arrested for embezzling discretionary diplomatic funds worth more than $¥ 500$ millions (Mainichi Daily News, 2001b). When this case was revealed, MOFA adamantly denied organizational complicity,claiming that only one individual was to blame. However, when several other fraud cases involving MOFA officials were disclosed, the ministry was forced to admit that corruption was endemic, involving approximately 30 divisions within the ministry (Johnson, 2001; The Japan Times Online, 2001a; The Japan Times 
Online, 2001b; The Asahi Shimbun, 2001b). These revelations of fraud stunned the public and gravely tarnished MOFA, which has become the subject of media and public mockery.

As these corruption scandals were revealed, public confidence in the integrity of the bureaucracy plummeted. The public learned that civil servants in Japan, the nation's elite, wield enormous discretionary power in an environment where information is confidential and where the bureaucracy-private sector relationships are often based on favoritism and extravagant gifts. Public trust in the bureaucracyplummeted.

\section{Psychological Confusion among Japan's Youth}

The declining of bureaucratic authority has been paralleled by increased activism of citizens' groups that demand state accountability and political and economic reforms in Japan. One of the most important factors that has contributed to the NGO movements is the changing values of the youth who have begun to search for new meaning in a postindustrial society.

As the Japanese have become one of the wealthiest peoples in the world, they have begun to sense that they have achieved their nation's long-standing goal since the 1868 Meiji Restoration: to catch up with the West. The single-minded pursuit of economic growth and the worship of an ideology of "GNPism" (Curtis, 1999a, p. 3) after World War II indeed unified Japan and helped it to become a rich country. The quest to catch up with the West, in economic terms, was an important national goal during the Cold War era, when national security matters such as defense and the constitutional order were sensitive issues that often divided people into right and left camps. The government emphasized the unifying themes of economic development and won a strong national 
consensus to concentrate the country's energies on fostering a rapid increase in GNP (Curtis, 1999b).

Now, however, the Cold War is over, and Japan has become a wealthy country. Accordingly, the pursuit of economic development is no longer the sole goal of the Japanese people, especially for the younger generation. Although they still want their country to prosper, many young people today reject the lifestyle that accompanied the economy-first policy. They no longer want tosacrifice their lives by working 60-70 hours a week for the welfare of their nation and companies (see Nikkei Weekly, 2001).

As people have lost a clear sense of direction, traditional aspects of the society have also eroded, resulting in a weakening of the patriarchal family system. The erosion of traditional values has created new social problems, demonstrated recently by an increase in youth violence and the spread of the Aum Shinrikyo (now called "Aleph"), the religious cult group that killed 12 people and injured more than 5,000 people on the Tokyo subway in a sarin gas attack in 1995. Many of such problems can be explained by the alienation of the youth that grew up in material affluence but lacking spiritual meaning. During the developmental state era, people concentrated all their energies on economic recovery from the devastating war and creating rapid GNP growth which, in a sense, gave them spiritual satisfaction. In the post-developmental state era, many people are searching for new meaning in their lives. As Castells (1998) observes, commenting on Japan:

An increasingly confused society, particularly in its younger sections, having grown up in affluence, becomes deprived of meaningful values, as the traditional structures of familial patriarchalism and bureaucratic indoctrination lose their grip in a culture filled with information flows from diverse sources. A mixture of ritualistic Japanese traditions, 
American icons, and high-tech consumption fills the vacuum in social dynamics, cultural challenges, or personal dreams of a society that has finished its assigned task: to make Japan secure, rich, and respected within 50 years. Now, after their strenuous effort, the Japanese find the tunnel at the end of the light, as increasingly abstract, new technocratic challenges are proposed by a developmental state that has outlived the state of emergency. According to sociological studies, most people want to enjoy the quiet consumption of the good life, meaning less karoshi (death due to overwork), more vacation, better housing, better cities, and a life without exams; while young people bursting with the energy of their increasingly liberated passions, search for ways of experimentation (parenthesis added) (p. 235).

At the same time, many young people have begun to find new meaning in life through the adoption of global social values. Growing numbers of Japanese have become exposed to global norms through media, foreign travel, or foreign study. They have begun to develop a transnational consciousness to help solve pressing problems in the world, especially in the post-Cold War era when global concerns have shifted from security to issues such as human rights, AIDS, and the environment (Asahi Shimbun Online, 2000; Asahi Shimbun Chikyu Project 21, 1998).

This growing consciousness of global affairs and norms is matched by the acquisition of organizing skills. Globalization and the spread of technology have made citizens more skillful in collecting and utilizing information. This "skill revolution," together with the acquisition of global norms, has changed the nature of political authority. Citizens are becoming more knowledgeable on issues that concern them and less deferential to traditional sources of authority (Rosenau, 1990; Rosenau and Fagen, 1997; Rosenau, 1997). In the case of development and foreign aid, many NGO workers are more knowledgeable about certain issues and needs in developing countries than are Japanese bureaucrats working on ODA in Tokyo or elsewhere. These NGO workers do not blindly accept state foreign aid policies, but challenge themwhen necessary. 
In this context, the 1980 s and especially the 1990s witnessed a revival of social movements in Japan that had been dormant since the environmental movements of the 1960s. The new social movements are different than those of the '60s, though. In the '60s, social movements were localized; citizens were primarily concerned with their own regional affairs (Steinhoff, 1989). In contrast, people's concerns today expand beyond their own regional and national borders. Some even find local-global linkages in a variety of issues, including the environment and human rights (Asahi Shimbun Chikyu Project 21, 1998). Today's activists think globally.

The changing societal trends - economic recession, bureaucratic corruption, and alienation of the youth and search for new meaning in life-have influenced people's attitudes toward both the state andsociety; trust and confidence in the state has plummeted while individual autonomy has been on the rise. More Japanese believe that they cannot count on state leadership in economic affairs but that they have to rely on themselves. Rather than prioritizing the welfare of the state as a whole, they feel that they should individually pursue their own well-being first (Ono, 2001). Also many people, especially the youth, have gained confidence in themselves due to the acquisition of knowledge and skills. They are becoming more autonomous and are no longer inhibited from expressing new ideas. They have started organizing and joining citizens' groups to express their beliefs and values. This change in people's attitudes has begun to transform transform state-civil society relationsas growing numbers of people are willing to challenge state authority.

\section{State-Civil Society Relations}

This increased of citizen activism is reflected in an expanding, and increasingly confident, NGO movement in Japan. This is reflected, especially, in areas related to overseas aid and development. The expanding influence of NGOs in Japanese ODA has 
been mentioned by a number of observers (see Rix, 1993); however, the potential significance of such expansion has not been explored. In particular, the following questions beg to be addressed. What kind of relationships are being forced between MOFA and NGOs? How do different perspectives and approaches within the NGO community affect state-NGO relations? To address these questions, the last part of this paper provides an overview of Japanese NGOs engaged in international aid, examining the history of Japanese NGOs, MOFA-NGO relationships, divisions with the NGO community over relations with MOFA, and the impact of NGO involvement with MOFA.

\section{Historical Development of Japanese NGOs}

In legal terms, Japanese NGOs consist of two distinct groups: incorporated associations and unincorporated associations. The majority of Japanese NGOs are unincorporated associations that have no legal status. In contrast are the incorporated associations, some of which are highly regulated by the state. Two specific types of incorporated associations that are commonly referred to and treated as NGOs by the Japanese ODA administration and the NGO community are (1) public interest corporations (kôeki hôjin), established under Article 34 of the Civil Code of 1896, and (2) specified nonprofit activity associations (tokutei hi-eiri katsudô hôjin), former unincorporated associations that changed their status with the enforcement of the Law to Promote Specified Nonprofit Activity of 1998 (commonly known as the NPO Law).

While the proliferation of Japanese NGOs engaged in international aid and development is a recent phenomenon, in the last two decades the growth of NGOs devoted to this field has been dramatic. In a directory of Japanese NGOs engaged in international cooperation, only 59 were listed in 1980. In 1993, the number reached 290, and in 1996 there were 368 (Japanese NGO Center for International Cooperation, 1994; Saotome, 1999). As most Japanese NGOs are unincorporated and not registered with the government, their exact number is difficult to determine. There may be far more than listed in the directory. 
While many Western NGOs emerged in the 1940s and 1950s to assist European rehabilitation after World War II, most Japanese NGOs, especially unincorporated associations, were started in the 1980s and 1990s, almost half a century later. The majority of the Japanese NGOs established prior to the 1980s were either Christian in origin or incorporated associations with strong ties to the government (Japanese NGO Center for International Cooperation, 1998b).

The relatively late emergence of Japanese NGOs - unincorporated associations in particular-can be understood in light of Japanese culture, society, and politics. At least four factors seem particularly relevant. First, unlike Western and some developing countries, Japan does not have a Christian evangelical tradition based on volunteerism and charity. Although some Japanese converted to Christianity and became engaged in charitable work in the past, their influence was limited and their values of Christian voluntarism and charity did not take deep root in Japan (Yamaoka, 1998). Second, Japanese society is group-oriented and thus people tend to give mutual assistance within their own groups (usually the family or company) before extending such assistance to others. In particular, the Japanese concept of the uchi (inside) and soto (outside) discourages anyone from assisting those who do not belong to his or her own group. Third, Japanese society values order. Individuals and NGOs critical of the government were viewed as anti-government and prone to cause social disturbance and instability. This view was reinforced during the Cold War era, when many activist NGOs were regarded by government officials as communist or radical left-wing organizations. Most importantly, the Japanese governments from the Meiji era (1868-1913) exerted strong influence over citizens' activities through the establishment of incorporated associations based on the Civil Code of 1896. Since most of these organizations were strictly controlled by the state and functioned as an arm of the state's welfare policy, there was little basis for purely private activities (Yamaoka, 1998). In turn, the reliance of the Japanese on state-led incorporated associations for the provision of social services raised 
skepticism and suspicion toward unincorporated citizens groups. To many Japanese, these unincorporated organizations appeared illegitimate.

The first rapid expansion of Japanese NGOs began in the late-1970s and the early-1980s as a response to the Indochinese refugee crisis. The mass media, particularly television, appealed to Japanese with vivid images of Vietnamese, Cambodian, and Laotian refugees desperately trying to escape their countries. The images of their suffering were so powerful that they prompted Japanese individuals - mostly youth in their twenties - to take action to provide assistance. It was a "historical experience" (Matsui, 1990, P. 215) of ordinary citizens-students, doctors, and nurses - to cross the national border for the first time to volunteer assistance to another people. From the Thai border camps emerged pioneer Japanese NGOs, such as the Japan International Volunteer Center (JVC) and the Japan Sotoshu Relief Committee (JSRC).

While many early NGOs first worked on emergency relief activities for Indochinese refugees on the Thai-Cambodian border camps or in Japan, they have gradually expanded their scope of activities over the years, addressing root causes of poverty and vulnerability to natural disasters. These NGOs are now interested in providing developmental assistance in areas such as environmental protection, agricultural development, social welfare, primary education, and anti-landmine campaigns.

Since the early Japanese NGOs launched their activities in Southeast Asia, this region has remained as the center stage for both old and new NGOs. Like the first-wave NGOs which concentrated their activities in Thailand, many of the newly-established NGOs have focused on Southeast Asia, in particularThailand, the Philippines, and Indonesia. Indochina, especially Cambodia, has also attracted many Japanese NGOs since the early 1990s due to the peace settlement in that country and the easing of restrictions on foreign NGOs by the Cambodian government. 
While the Indochina refugee crisis had an important impact on the growth of Japanese NGOs in the late-1970s and early-1980s, Japanese civil society has been further mobilized since the mid-1990s by another tragedy, this time within Japan itself: the Great Hanshin Earthquake of 1995, which killed more than 6,000 people and left 30,000 people homeless in the Kobe region. The Japanese government dithered in its response to the crisis and failed to mobilize domestic resources quickly enough or even to allow international governments and organizations to deliver emergency assistance. In response, a great number of individuals - estimated at more than 1.3 million - rushed to help the victims with much-needed food, medicine, and other supplies. The earthquake became "a watershed event for the development of a civil society in Japan" (Japan Center for International Exchange, 1996, n.p.), fueling intensive discussion on the role of civil society and creating a broader awareness of the need to foster citizens' groups. The Great Hanshin Earthquake became a catalyst for both the growth of pre-existing citizens' groups and the launching of many new groups. And since then, many organizations engaged in earthquake relief operations have extended to other project areas such as international aid, development, education, and environmental protection.

\section{NGO Advocacy}

In the field of ODA, the Japanese bureaucracy is not insulated from civil society. NGOs try to influence state policy with a diverse range of strategies. Some focus on advocating policy, sometimes struggling against government policies and programs. Others cooperate with the state by joining government-NGO bodies to formulate policy and/or taking on contracts for aid implementation. A handful combine advocacy and cooperative activities in their relations with the state.

Since the mid-1980s, Japanese private citizens have launched grassroots groups to investigate how the Japanese government manages its rapidly expanding ODA program in collaboration with Japanese businesses and recipient governments. One such group is the Reconsider Aid Citizens' League (REAL), established in 1986 by Sophia University 
professor Yoshinori Murai. REAL is Japan's first NGO dedicated to changing Japanese aid.

In the late-1980s, many NGOs, mostly leftist groups, began campaigning for aid reform. Operating aid projects in developing countries, these groups tried to present views from the developing world and look behind the official rhetoric of Japan's aid. In order to pressure Japan's aid programs to improve, they held seminars and meetings and frequently appeared in the media, exposing cases of ODA failures, corruption, mismanagement, and misuse of funds. Their central point was that many ODA funds mainly recycle to the coffers of Japanese firms and that Japanese officials tacitly approve acts of corruption and injustice, harming the interests of the local people who should be the beneficiaries of Japanese aid. ${ }^{3}$

Japanese advocacy NGOs, working in conjunction with NGOs of other countries, have achieved some success in halting Japan's ODA projects since the late 1980s. One key victory was achived in 1990, when Japanese environmental NGOs, such as the Friends of the Earth Japan, forced MOFA and the other ministries to abandon a loan project for the construction of a large-scale hydro-electric plant for the Sardar Sarovar Dam (commonly known as Narmada Dam) on India's Narmada River. This project was part of the Narmada Valley Project planned by the Indian government to construct a large number of dams, irrigation canals, and power plants on the river over several decades. The Japanese NGOs were particularly angry at their government's role in the hydropower plant project for the Sandar Sarovar Dam, as it was estimated that this dam alone would cause the resettlement of some 100,000 people living in 230 villages (Sumi, 1990). Friends of the Earth Japan and other Japanese NGOs worked in close cooperation with the local communities in the river basin and with other environmental groups in India and the West. Japanese NGOs mounted public campaigns in Japan to protest the construction of the dam and the power plant, holding symposia and informing the media of the likelihood of environmental destruction. They also lobbied both the Japanese 
government and the World Bank, the main sponsor for the Sandar Sarovar Dam project, to reconsider their funding (Sumi, 1990). In the face of NGO pressure, Tokyo rescinded its involvement in the loan project in 1990, followed by the World Bank in 1993.

An equally notable victory for NGOs was the 1993 cancellation of Japanese pesticide aid to Cambodia in a grant aid project providing chemical fertilizer and agricultural machines as part of the Kennedy Round II (an international donor agreement to increase agricultural production in developing countries). Japanese NGOs such as the Japan International Volunteer Center (JVC), together with International NGOs in Cambodia, campaigned to stop this project, which they saw as harmful to the local environment. JVC campaigned by writing letters to MOFA, holding symposia, and publishing a booklet to inform the public of the danger of the pesticide aid. The NGOs' efforts caught the attention of the media and MOFA finally yielded to NGO pressure and ended the aid, thus making an about-face on the ministry's claim that the pesticides were environmentally safe. This was a major victory for Japanese NGOs, especially given the fact that major Japanese chemical corporations - including Sumitomo Chemical and Itochu Corporation - lobbied hard on behalf of the program, even holding seminars with state officials in Cambodia to convince them of the need for pesticides (Japan International Volunteer Center, 1993; Japan International Volunteer Center, 1995). The success of NGOs in mobilizing against and defeating an initiative that was strongly backed by Japanese industry — and which would have brought substantial economic benefit to influential chemical corporations - was an important indication that the statebusiness alliance no longer held uncontested power in Japan.

These examples indicate that NGOs are increasingly playing an important role in aid and development policy making. Although NGO “victories” over MOFA are still limited in number, these examples are indicative of the current and future trends of NGO activism in ODA policy making. Prior to the mid-1980s, NGOs had had no wellcoordinated campaigns against the government's aid programs and projects and had 
exerted virtually no influence in Tokyo's aid policy. In the second half of the 1980s, a few NGOs launched campaigns against ODA projects in Southeast Asia (e.g., the Japan Tropical Forest Action Network's campaign against a Japanese ODA project in Sarawak, Malaysia), but their advocacy efforts did not bear fruit. The turning point was the aforementioned Narmada campaign of 1989-1990 in which Japanese NGOs were able to influence the Japanese government's aid policy for the first time. Since the Narmada campaign, Japanese NGOs have proved that they could serve as a watchdog of government's aid policies and that they could effectively terminate aid projects that they consider harmful to the aid recipients.

Those engaged in advocacy are independent and do not hesitate to express themselves, often articulating their agendas in public. But these advocacy groups are not abolitionists who advocate eliminating Japanese ODA or deny the value of giving aid. They are reformists that by and large accept the reality of the continued existence of ODA programs. An increasing number of progressive NGOs have begun to evaluate the effectiveness of confrontational advocacy and explore alternative methods in dealing with government officials. In particular, they are searching for common ground with reformoriented MOFA officials to bring about changes incrementally, starting from where MOFA can comply with NGOs' demands. In the area of ODA, MOFA usually makes the final decision in policy matters but it attempts to accommodate various interests, including those of NGOs, before forming the policy. Thus it is important for NGOs to provide input to reform-minded MOFA officials to influence aid policy.

\section{NGO-State Partnership}

The success of NGOs to induce policy change largely depends on their ability to engage with state officials. While easy access to officials does not guarantee policy impact, accelerating mutual understanding through dialogue is one of the most important steps of NGOs to change aid policy. 
The relationship between Japanese NGOs and the state changed in the 1990s, moving towards more collaboration and dialogue. The interaction between NGOs and MOFA occurs mainly in three forms: financial assistance, policy dialogue, and operational collaboration. The Japanese government's first gesture was financial assistance: simple, one-way transfers of money from the government to NGOs. Several sources of funds are now available to Japanese NGOs from local governments (e.g., Tokyo, Kanagawa) and various ministries (e.g., MOFA, the Ministry of Posts and Telecommunications or MOPT, the Environmental Agency, the Ministry of Forestry and Fishery, the Ministry of Health and Welfare). The most significant sources of funding for Japanese NGOs are two funds from MOFA initiated in 1989 (the Subsidy Funds for NGO Projects, and Grant Assistance for Grassroots Projects) and one from the Ministry of Posts and Telecommunications (MOPT) launched in 1991 (the Volunteer Postal Savings International Aid). MOFA's funding for NGOs has rapidly increased since 1989 despite Japan's economic recession in the 1990s. By 1998, the Subsidy Funds for NGO Projects had grown to ten times that of 1989 (from approximately 112 million yen to 1.15 billion yen) and the Grant Assistance for Grassroots Projects had expanded approximately 19fold (from about 300 million yen to 5.7 billion yen) (Saotome, 1999). ${ }^{4}$

Policy dialogue refers to "an attempt to influence policy through information exchange and debate that explores both differences and areas of agreement" (Covey, 1998, p. 82) between NGOs and the state. Policy dialogue takes place formally through committees and study groups involving government officials and NGO members, and informally through casual interactions at conferences and seminars. Policy dialogue is “insider” advocacy (Covey, 1998, p. 82), seeking incremental reform rather than a radical fundamental shift. Policy dialogue does not employ high-pressure "street protest" tactics, but effectively builds up trust and partnership between NGOs and state officials. But for NGOs to impact state policy, they have to be seen as legitimate. They must conform to 
the rules of the game and behave accordingly or concede to the particular views and values of state officials.

Until the 1990s, MOFA and NGOs had very few channels through which to exchange views and information. In the mid-1990s, however, the government began to invite NGO leaders to participate in a variety of policy forums. For example, complying with an NGO request, the Japanese government appointed three NGO representatives as official delegates to the 1994 Cairo International Conference on Population and Development. For the first time, NGO members were selected as part of a Japanese government delegation, and their participation in the international conference at the invitation of the Japanese government was a significant step for the Japanese NGO community towards more international visibility and influence (Ikegami, 1996).

In the 1990s, MOFA and NGOs began to hold numerous seminars, symposia, and conferences to promote dialogue. In addition, Japanese NGOs and state officials have formed councils that hold regular meetings to discuss issues related to humanitarian assistance to developing countries and state funding of NGOs. The most important ongoing meeting between NGOs and state officials is the NGO-MOFA Regular Council Meeting. The council, started in 1996, usually meets quarterly and involves about ten representatives from the NGO community and another ten from different divisions within MOFA.

Originally, the council's main purpose was to discuss issues related to MOFA's funding schemes (i.e., Subsidy Funds for NGO Projects and Grand Aid for Grassroots Projects). Gradually, broader topics have been included at the macro level, including untied aid policy, debt relief, and grant aid policy. NGOs are given an opportunity to express their views of Japan's ODA policy. One positive note of the NGO-MOFA Regular Council Meetings is that the meetings are not packed, as might be expected, with pro-government NGOs. On the contrary, independent NGOs represent the whole NGO community, selected by MOFA to be its counterparts at the meetings. Many active NGO 
members participating in the NGO-MOFA Regular Meetings are representatives of independent NGOs.

The NGO-MOFA Regular Council Meeting has led to other important fora of NGO-state interaction. These include a Subcommittee to Achieve the Objectives of the ODA Reform Council's Final Report in 1999, and NGO-Japan International Cooperation Agency (JICA) Council Meeting, which began in 1998. JICA is an aid implementing agency under the jurisdiction of MOFA. The policy dialogues between NGOs and MOFA/JICA staff have created an environment where both parties listen to each other and learn about their different beliefs. Dialogues have offered opportunities for mutual discussion about the relative strengths and weaknesses of NGOs and the government in promoting development and implementing aid projects. Over time, these policy dialogues are providing opportunities for the increased input of NGOs in ODA policy making. In other words, these policy dialogues allow NGOs to gain many points of access to policy making - an important characteristics of pluralism.

Finally, policy dialogues resulted in operational collaboration with project-based NGO engagement. By such collaboration, NGOs participate in project-based policy making at the micro level and are directly involved in all phases of aid implementation. During the NGO-MOFA Regular Council Meetings, NGOs and MOFA decided to start joint evaluation of ODA projects. Also, MOFA decided for the first time in 1999 to contract out ODA grassroots projects to NGOs (as well as to universities and local governments) on a regular basis. Unlike the United States Agency for International Development (USAID), which heavily relies on NGOs for aid project implementation, the Japanese government did not previously have a subcontracting system for unincorporated NGOs and universities. Although in the 1970s and 1980s JICA had on an irregular basis contracted the staff of several NGOs for research and training, these NGOs were all incorporated organizations (Japan International Cooperation Agency, 1996). But in 2000, the NGOs working as contractors included unincorporated organizations. ${ }^{5}$ 
Government financial assistance to NGOs, state-NGO policy dialogue, and operational collaboration of NGOs and the state, all of which started in the late-1980s and the 1990s, have been positive steps in enhancing the role of NGOs in development. With more access to funding and greater opportunity to voice their views, NGOs have begun to influence MOFA's policies.

However, sharp differences in perspectives still remain between NGOs and MOFA. NGOs argue that aid should benefit the people in the recipient countries first, rather than benefit Japanese interest groups or government agencies. In contrast, MOFA officials fundamentally strive to create and consolidate their own power base within the government, an interest which sometimes puts the ministry at odds with the views of NGOs.

It is also important to point out that the interaction between NGOs and the bureaucracy is characterized by patterned pluralism; NGO participation in aid policy making is not free-flowing or unrestricted, but limited and controlled. MOFA overseas the process and, together with other agencies within the bureaucracy, takes ultimate responsibility for aid decision-making. NGO collaboration in decision-making is on an invited basis, with a MOFA inviting a limited number of actors to participate. The NGOs usually involved in various meetings with the bureaucracy are relatively large ones that play a leadership role within the Japanese NGO community. They are representatives of the Japan NGO Center for International Cooperation (JANIC), an NGO coordinating center consisting of approximately 65 NGOs (Japan NGO Center for International Cooperation, 2001). The bureaucracy, including MOFA and JICA, mainly deal with JANIC representatives, but not with any NGOs eager to have direct dialogue with state officials. Interestingly, the majority of the NGOs that have regular contact with bureaucrats are either moderate or leftist, relatively large groups that are often critical of state aid policy. These groups are most active at JANIC and represent the NGO coordinating center. Excluded from the interaction with MOFA are small NGOs 
located outside the Tokyo area. Some of these NGOs are not JANIC members. Others are members but do not take active part in JANIC largely because of geographical distance. Also, conservative NGOs are often out of the loop. They do not get along with leftist NGOs which, in their view, dominate JANIC, and thus do not represent the coordinating center for meetings with MOFA. ${ }^{6}$ In short, the Japanese NGO community is diverse and only certain types of NGOs have direct contact with MOFA and have the opportunity to influence the ministry's aid policy.

\section{Modes of Interaction}

As Japanese NGOs are increasing their profile in international aid, the types of NGO-state relations become an increasingly important factor affecting the course of Japan's future aid policy. Four modes of interaction are relevant to NGO-MOFA relations: conflict, co-optation, critical cooperation, and disengagement. Although many observers of civil society tend to see NGO-state relationship in dichotomy-conflict or co-optation - a closer examination reveals that NGOs can be simultaneously highly critical and highly cooperative (critical cooperation). Critical cooperation allows NGOs to work willingly with the government while maintaining autonomy and critical distance. In contrast, disengagement involves low conflict and low cooperation (Covey, 1998).

Of the four modes of interaction, critical cooperation and co-optation best characterize the relationships that most large NGOs have with the ministry. NGOs engaged in critical cooperation challenge the state's ODA policy while simultaneously cooperating with MOFA officials via policy dialogues and operational collaboration. These NGOs may occasionally use protest and advocacy as reform strategies, but they apply "soft" advocacy (i.e., policy dialogue) more frequently than confrontational strategies. Since MOFA has begun to open its doors to constructive dialogue, some NGO leaders feel they no longer have to shout anti-government slogans to gain attention. ${ }^{7}$ NGOs considered to be "co-opted" by the government are usually pragmatic groups that try to benefit as much as possible from working with government officials. They seek 
contracts from the government aid agencies and try to foster close relations with bureaucrats for that purpose. ${ }^{8}$

The emergence of MOFA-NGO cooperation raises important issues of state-civil society relations. Such cooperation can be both beneficial and detrimental to MOFA and NGOs. For MOFA, cooperation with NGOs can help the ministry gain public support for ODA. Japan has been going through important social and economic changes manifested by the crisis of state authority and an increase of citizens' influence in politics. The state has become subject to public demands for accountability and can no longer ignore citizens' views of policies. Working with NGOs is advantageous for MOFA because NGOs are usually viewed as representatives of Japanese civil society. One of the disadvantages of working with NGOs, however, is the risk of providing funding to organizations incapable of effectively implementing projects or to those not genuinely interested in providing quality services to recipients but merely motivated to expand their operations through public funding. For NGOs, cooperation with MOFA can mean a steady flow of financial assistance, desperately needed by many Japanese NGOs. Many NGOs also hope to influence ODA policy by cooperating with MOFA in a manner of critical cooperation. The most serious drawback for NGOs cooperating with MOFA is the risk of co-optation. Through cooperation with the state, NGOs may lose their autonomy and be forced to tailor their activities to the priorities of MOFA rather than to the people whom they intend to represent (i.e, Japanese civil society) and the communities they intend to serve (recipients of development aid). State funding may distort NGO missions by enticing NGOs to do things they would not otherwise do. The fear of "vendorism" (Salamon and Anheier, 1996, p. 103), or the distortion of organizational missions in pursuit of state funding, is strong among many NGOs lacking a strong financial basis. For these reasons, great care is needed for both sides to manage the partnership effectively, balancing potential risks and opportunities. 


\section{Conclusion}

By focusing on changing state-civil society relations in Japanese ODA policy, this study emphasized that there are more political openings for citizens' groups engaged in development and aid today than ever before. Advocacy groups can make their voices heard via mass media, public seminars and conferences, and other means. Some NGOs have direct contact with MOFA officials through regular meetings where they can express their viewpoints. Also, some NGOs have begun implementing ODA projects under a new contracting program that started in 1999. NGOs have now entered the political arena, attempting to influence ODA policy.

The empirical data in this paper suggest that the developmental state model that shed light on Japan's political economy during the period of rapid economic growth in the 1950s-1970s has outlived its usefulness. The developmental state is based on the notion that only the bureaucracy, in close collaboration with the corporate sector, exerts influence over aid policy making. On the contrary, the present study claims that Japanese aid decision making is pluralistic. The emergence of NGOs as lobbyists against the Japanese ODA program runs contrary to the conventional wisdom about the kinds of players that can influence aid policy making. But NGO influence is increasing and is likely to continue expanding in the future. In this regard, the state is not autonomous from civil society, but rather it accommodates the needs of civil society.

Yet the participation of civil society in aid decision making is not based upon open-ended pluralism. Rather, it involves controlled, patterned pluralism in which NGOs and the bureaucracy, MOFA in particular, interact with each other in both confrontation andcooperation. While challenging bureaucratic authority by launching advocacy campaigns against aid projects and policies, NGOs have institutionalized relationships with MOFA through cooperative arrangements (i.e., financial assistance, policy dialogue, and operation collaboration). At the same time, in the patterned pluralist system of ODA policy making, certain NGOs - relatively large, moderate to leftist NGOs - are invited to 
MOFA-NGO regular meetings, but not all NGOs have access to aid policy making. Similarly, political participation is limited.

The Japanese state has traditionally provided little space for the development of an independent NGO community, and NGOs were indeed irrelevant for ODA policy making until the late-1980s. Since then, however, the state has been slowly opening up policy space for NGOs, leading to more pluralism in the ODA policy-making environment.

Of course, aid and development issues represent only one component of the broader political and economic agenda in Japan. This study did not attempt to analyze the role of civil society activism on other political issues in Japan, or to compare this activism to that of other industrialized countries. Further research will be necessary for cross-issue or cross-national comparisons. However, it is important to point out that overseas aid and development are critical political issues in Japanese society. Since Japan has not carried out any overseas military activity since World War II (other than recently sending a few support ships to Afghanistan), Tokyo must project its political and economic influence in international affairs through economic and diplomatic means. Because of this, Japan is the largest aid donor in the world, surpassing the U.S. in the late 1980s, even though the Japanese economy is only $60 \%$ as large as that of the US. Japanese citizens are fully aware of Japan's overseas aid and development commitments, and policy in these areas is as important in Japanese politics as are issues of military intervention in US politics. Thus, it is not surprising that Japanese citizens have organized themselves most vociferously on issues related to aid and development, and this may well serve as the harbinger of greater citizen activism in Japan in the twentyfirst century. With expanded political pluralism now clearly evident in one important arena, it will not be a surprise if this same trend emerges in other policy areas in Japan in the future. 


\section{Notes}

${ }^{1}$ Pempel (1998), for example, argues that Johnson's argument on bureaucratic autonomy was undoubtedly true of a Japan prior to the mid-1970s, when MITI exerted great influence over the corporate sector by promoting industrial policy that would enhance Japanese firms' competitiveness in international markets. However, in his viewpoint, Johnson's argument has become untenable for Japan since the 1970s. In this view, large Japanese firms have gained knowledge, technology, and expertise and no longer require MITI's protective guidance. These firms have demanded that the state adapt a laissez-faire policy.

${ }^{2}$ The Sagawa scandal involved LDP members and former civil servants. Longtime LDP leader Shin Kanemaru was arrested in March 1993 and charged with receiving a payoff of about 500 million yen from a trucking firm (Sagawa Corporation) that was seeking special treatment from transport regulators. Another influential LDP member who once served as minister of Construction, Kishiro Nakamura, and several former civil servants in local governments were also implicated in the Sagawa case. In the jusen housing loan scandal, MOF and the Ministry of Agriculture, Forestry, and Fishery (MAFF) were the targets of public criticism. MOF, supported by MAFF, spent approximately US $\$ 6.85$ billion of tax money to save bankrupt jusen institutions that provided amakudari posts to retired MOF and MAFF officials (Inoguchi, 1997). In the 1996 HIV case, officials at the Ministry of Health and Welfare permitted the sale and use of HIV-contaminated blood by pharmaceutical firms for blood transfusions for hemophiliac patients, even though these officials were aware of the potential danger (Inoguchi, 1997).

${ }^{3}$ Critics, however, point out that these groups were interested in publicizing ill-effects of aid on people in recipient countries and thus that they paid little attention to seemingly successful programs or welldesigned projects which do benefit the poor. According to this view, groups like REAL selected examples of bad aid projects, including ill-planned cultural centers and environmentally-harmful hydro-electronic dams, and informed the public about damages done to the poor in the developing world.

${ }^{4}$ MOPT' Volunteer Postal Savings International Aid is not subject to the yearly budgetary system. Strictly speaking, it is not considered part of ODA funds, but is included here because it is a major source of revenue for NGOs. Holders of this ordinary postal savings account (approximately 24 million people) designate that 20 percent of their after-tax interest will go to NGOs via MOPS. Due to falling interest rates 
in Japan, however, the fund fell from a high of 2.8 billion yen in 1995 to 1.2 billion yen in 1999 (Ministry

of Posts and Telecommunications, 1999).

5 Minutes, NGO-MOFA Regular Council Meeting, June 23, 1998.

${ }^{6}$ Interview with Secretary General of the Association of Medical Doctors of Asia (AMDA) in Tokyo on March 3, 1997.

${ }^{7}$ Interview with Chief Program Officer at the International Program and Research Division of the Shanti Volunteer Center (SVC) in Tokyo on August 4, 1999; interview with officer at the International Relief Division of the Japanese Red Cross Society in Tokyo on February 1997.

${ }^{8}$ Interview with Secretary General of AMDA in Tokyo on March 3, 1997.

\section{References}

Allison, G. T. (1971). Essence of decision: Explaining the Cuban missiles crisis. Boston: Little Brown.

Amenomori, T., and T. Yamamoto. (1998). Introduction. In T. Yamamoto (Ed.), The nonprofit sector in Japan. Manchester: Manchester University Press.

Arase, D. (1994). Public-private sector interest coordination in Japan's ODA. Pacific Affairs, 67 (Summer), 171-199.

Arase, D. (1995). Buying power: The political economy of Japan's foreign Aid. Boulder and London: Lynne Rienner.

Asahi Shimbun. (1998, April 28). Okura shokuin no shobun risto, p. 3.

Asahi Shimbun. (2001b, September 11). Gaimushô, yaku-30-ka ni uragane, p. 1.

Asahi Shimbun Online. (2000, January 16). Watashitachi no 15-nen, ikyô taiken ga Nihon o kaeta: Tayô na kachikan mebaeru. Available: http://www.asahi.com/life/travel/116.html [January 16, 2000].

Balaam, D. N. and M. Veseth. (in press). Introduction to international political economy. Upper Saddle River, NJ: Prentice-Hall.

Blaker, M. (1993). Evaluating Japan's diplomatic performance. In G. L. Curtis (Ed.), Japan's foreign policy after the cold war: Coping with change. Armonk, New York: M.E. Sharpe. 
Bloch, J. C. (1989). A U.S.-Japan aid alliance: Prospects for cooperation in an era of conflict, USJP Occasional Paper (Vol. 89-07), Program on U.S.-Japan Relations, Harvard University.

CARE International. (1999). CARE 1998 annual report: 1998 CARE USA overview. Available: http://www.care.org/publications/annualreport98/care_usa_overview.html [1999, November 2].

Castells, M. (1998). End of millennium. Oxford, UK: Blackwell Publishers.

Citizens-NGOs Coordination Council for ODA Reform. (1997). ODA kaikaku ni mukete no teigen. Tokyo: Citizens-NGOs Coordination Council for ODA Reform.

Covey, J. G. (1998). Is critical cooperation possible? Influencing the World Bank through operational collaboration and policy dialogue. In J. A. Fox and L. D. Brown (Eds.), The struggle for accountability: The World Bank, NGOs, and grassroots movements. Cambridge, MA: The MIT Press.

Curtis, G. L. (1999a). Japan at the crossroads, Asia Pacific issues analysis from the EastWest Center, 41 (September).

Curtis, G. L. (1999b). The logic of Japanese politics: Leaders, institutions, and the limits of change. New York: Columbia University Press.

Dahl, R. A. (1961). Who governs? New Haven, CT: Yale University Press.

Economist. (2000, January 8). Old battle, new strategy, 74-75.

Fingleton, E. (1995). Blindside: Why Japan is still on track to overtake the U.S. by the Year 2000. New York: Buttonwood.

Friedman, T. L. (1999, April 30). Japan's nutcracker suite, The New York Times on the Web. Available: http://www.nytimes.com/library/opinion/friedman/043099frie.html [1999, June 14].

Haas, M. (1989). The Asian way to peace. New York: Praeger.

Havens, T. R. (1987). Fire across the sea: The Vietnam War and Japan 1865-1975. Princeton, NJ: Princeton University Press.

Hook, S. W., and Zhang, G. (1998). Japan's aid policy since the cold war: Rhetoric and reality. Asian Survey, 38(11), 1051-1066.

Ikegami, K. (1996). Jizoku kanôna kaihatsu to NGO katsudô, Kokusai Mondai, 441(December), 29-50.

Inoguchi, T. (1997). Japanese bureaucracy: Coping with new challenges. In P. Jain and T. Inoguchi (Eds.), Japanese politics today: Beyond karaoke democracy? New York: St. Martin's Press. 
International Development Journal. (1998). Kokkai giin ni kiku: Yosan sakugen o keiki ni enjo no muda mo kezuru doryoku o, 502, 12-13.

International Development Journal (1999a). Kokkai giin ni kiku: Seido hirô o okoshiteiru gaikô ni bijon o shimeshinagara kassei-ka suru, 517, 18-19.

International Development Journal (1999b). Kokkai giin ni kiku: Seishin-ron dake no ODA kihon-hô wa hitstuyô nai, 510, 14-15.

Islam, S. (1991). Beyond burden-sharing: Economics and politics of Japanese foreign aid. In S. Islam (Ed.), Yen for development: Japanese foreign aid and the politics of burden-sharing. New York: Council on Foreign Relations Press.

Japan Center for International Exchange. (1996). The recent debate on the role of NPOs in Japan and private-sector responses, Civil Society Monitor (Fall). Available: Available: http://www.jcie.or.jp/civilnet/civil_soc_monitor/fall_96.html

Japan International Cooperation Agency. (1996). JICA Sateraito. Available: http://www.jica.go.jp/jicanews/jens9606/jcns9606-h01.html [1999, November 1].

Japan International Volunteer Center. (1993). Stop! Kikenna nôyaku enjo: Kanbojia shakai ni ima nani ga hitsuyo ka. Tokyo: Japan International Volunteer Center.

Japan International Volunteer Center. (1995). NGO kara mita ODA: Seidojô, risôjô no mondaiten. In K. Hashimoto (Ed.), Senryaku enjo: Chuto wahei shien to ODA no shoraizo. Tokyo: PHP Research Institute.

Japan Times Online (2001a, January 26). Fired foreign ministry official facing embezzlement charges. Available: http://www.japantimes.co.jp/cgibin/getarticle.pl5?nn20010126a1.htm [September 8, 2001].

Japan Times Online (2001b, September 8). Official says he padded bills for 20 years. Available: http://www.japantimes.co.jp/cgi-bin/getarticle.p15?nn20010908a5.htm [September 8, 2001].

Japanese NGO Center for International Cooperation. (1994). NGO data book: Sûji de miru Nihon no NGO. Tokyo: Japanese NGO Center for International Cooperation.

Japanese NGO Center for International Cooperation. (1998a). NGO dêta bukku 1998: Sûji de miru Nihon no NGO. Tokyo: Japanese NGO Center for International Cooperation.

Japanese NGO Center for International Cooperation. (1998b). NGO direkutorî 1998: Kokusai kyôryoku ni tazusawaru Nihon no shimin soshiki yôran. Tokyo: Japanese NGO Center for International Cooperation.

Japanese NGO Center for International Cooperation. (2001). JANIC no sei-kaiin dantai. Available: http://www.janic.org/kaiindantai.html [November 25, 2001].

Johnson, C. (1982). MITI and the Japanese miracle: The growth of industrial policy, 1925-1975. Stanford: Stanford University Press. 
Johnson, C. (1995). Japan, Who governs?: The rise of the developmental state. New York: Norton.

Johnson, D. T. (2001). Bureaucratic corruption in Japan, Japan Policy Research Institute Working Paper, no. 76.

Katz, R. (1998). Japan the system that soured: The rise and fall of the Japanese economic miracle. Armonk, NY: M. E. Sharpe.

Krauss, E. S. (1989). Politics and the policymaking process. In T. Ishida and E. S. Krauss (Eds.), Democracy in Japan. Pittsburgh: University of Pittsburgh Press.

Lindblom, C. E. (1977). Politics and market. New York: Basic Books.

Mainichi Daily News (2001b, September 4). Foreign ministry embezzler loved living the high life. Available: http://www12.mainichi.co.jp/news/mdn/searchnews/833368/diplomatic20fund-0-1.html [September 7, 2001].

Matsui, Y. (1990). Shimin to enjo: Ima nani ga dekiru ka. Tokyo: Iwanami Shoten.

McKean, M. A. (1976). Pollution and Policymaking. In T. J. Pempel (Ed.), Policymaking in contemporary Japan . Ithaca, NY: Cornell University Press.

Ministry of Foreign Affairs (Ed.). (1994). Japan's ODA annual report 1993. Tokyo: Association for Promotion of International Cooperation.

Ministry of Posts and Telecommunications. (1999). Kokusai borantia chokin. Available: http://www.volunteer-post.mpt.go.jp/kokusai/a2.html [1999, October 28].

Muramatsu, M., and Krauss, E. S. (1987). The conservative policy line and the development of patterned pluralism. In Y. Yamamura (Ed.), The Political Economy of Japan: the Domestic Transformation (vol. 1). Stanford: Stanford Press.

Nikkei Weekly. (1998, April 4). Scandals drain Finance Ministry’s power, p. 2.

Nikkei Weekly. (2001, January 8). White-collar workers seek nonprofit, p. 17.

Ono, Y. (2001, January 3). Japan's decline makes one thing rise: Individualism, The Asian Wall Street Journal, p. 1.

Orr, R. M. J. (1990). The Emergence of Japan's foreign aid power. New York: Columbia University Press.

Oxfam. (1997). The financial year 1996-97. Available: http://carryon.oneworld.org/textver/ocfam/atwork/anrev97/ar12.htm [1999, June 6].

Pempel, T. J. (1982). Policy and politics in Japan: Creative conservatism. Philadelphia: Temple University Press.

Pempel, T. J. (1998). Regime shift. Ithaca, New York: Cornell University Press. 
Pyle, K. B. (1989). The burden of Japanese history and the politics of burden sharing. In J. H. Makin and D. C. Hellmann (Eds.), Sharing world leadership: A new era for America and Japan (pp. 41-77). Washington, D.C.: American Enterprise Institute for Public Policy Research.

Richardson, B. M. and S. C. Flanagan (1984). Politics in Japan. Boston: Little, Brown and Company.

Risse-Kappen, T. (Ed.). (1995). Bringing transnational relations back in: Non-state actors, domestic structures and international institutions. Cambridge: Cambridge University Press.

Rix, A. (1980). Japan's economic aid: Policy-making and politics. New York: St. Martin's Press.

Rix, A. (1993). Japan's foreign aid challenge: Policy reform and aid leadership. London and New York: Routledge.

Rosenau, J. N. (1990). Turbulence in world politics: A theory of change and continuity. Princeton, NJ: Princeton University Press.

Rosenau, J. N., and W. M. Fagen (1997). A new dynamism in world politics: Increasing skillful individuals? International Studies Quarterly, 41(4), 655-686.

Rosenau, N. J. (1997). Along the domestic-foreign frontier: Exploring governance in a turbulent world. Cambridge: Cambridge University Press.

Roxas, S. K. (1996). Principles for institutional reform. In J. M. Griesgraber and B. G. Gunter (Eds.), Development: New paradigms and principles for the twenty-first century (pp. 1-26). London: Pluto Press.

Salamon, L. M. (1994). The rise of the nonprofit sector. Foreign Affairs, 73(4), 109-122.

Salamon, L. M. and H.K. Anheier (1996). The nonprofit sector in comparative perspective: An overview. Baltimore: Johns Hopkins University Institute for Policy Studies.

Saotome, M. (1999). Imakoso motomerareru ôru Japan no kokusai kyôryoku, Gaiko Forum, 127(March), 34-40.

Schoppa, L. J. (1997). Bargaining with Japan: What American pressure can and cannot do. New York: Columbia University Press.

Steinhoff, P. G. (1989). Protest and democracy. In T. Ishihara and E. S. Krauss (Eds.), Democracy in Japan. Pittsburgh: Univeristy of Pittsburgh Press.

Sugishita, T. (1998). NGO saizensen No. 14, Gaiko Forum, 116 (February), 82-83.

Sumi, K. (Ed.). (1990). Kirawareru enjo: Segin, Nihon no enjo to Narumada Damu. Tokyo: Tsukiji Shokan.

Uriu, R. M. (1996). Troubled industries: Confronting economic change in Japan. Ithaca, NY: Cornell University Press. 
Yamaoka, Y. (1998). On the history of the nonprofit sector in Japan. In T. Yamamoto (Ed.), The nonprofit sector in Japan (pp. 19-58). Manchester: Manchester University Press. 